\title{
HUMAN IMPACT ON THE BENTHIC MACROFAUNA OF TWO BEACH ENVIRONMENTS WITH DIFFERENT MORPHODYNAMIC CHARACTERISTICS IN SOUTHERN BRAZIL
}

\author{
Jenyffer Vierheller Vieira*, Carlos Alberto Borzone, Luciano Lorenzi and Fabiano Grecco de Carvalho
}

Universidade Federal do Paraná, Centro de Estudos do Mar, Departamento de Ciências da Terra, Laboratório de Ecologia de Praias

(Av. Beira Mar, s/n 83255-000 Pontal do Paraná, PR, Brasil)

*Corresponding author: jenyffervvieira@gmail.com

\begin{abstract}
A B S T R A C T
Pollution, exploitation of resources, erosion and recreational activities produce the most common impacts that somehow alter the natural balance of beach ecosystems. The aim of this study was to compare the richness and abundance of the benthic macrofauna of two sectors, one non-urbanized and the other urbanized, on each of two morphodynamically different beaches. Sectors of each beach were analyzed taking into account morphodynamic, anthropogenic (recreational activities) and ecological aspects. Morphodynamically, one of the beaches presented sediment formed of fine sand with a gentle slope and morphodynamism with dissipative characteristics. The other was of sediment formed of medium sand with a steep profile and of intermediate to reflective morphodynamic characteristics. On both beaches during the summer, the urbanized sector was frequented by a greater number of users than the non-urbanized sector. On the beach with dissipative morphodynamism, negative relationships were observed between user abundance and the species Bledius bonariensis, Donax hanleyanus, Thoracophelia furcifera, Excirolana armata, Phoxocephalopsis sp. and Tholozodium rhombofrontalis. On the beach with intermediate to reflective morphodynamics, low abundances of Atlantorchestoidea brasiliensis and Excirolana braziliensis were recorded in the urbanized sector. Thus the results of this study suggest the use of certain species as indicators of human impacts on beach ecosystems.
\end{abstract}

\section{RESUMO}

Poluição, exploração de recursos, erosão e atividades recreativas são os impactos mais comuns que de alguma forma alteram o equilíbrio natural do ecossistema praial. O objetivo deste trabalho foi comparar a riqueza e a abundância da macrofauna bentônica entre um setor não urbanizado e outro urbanizado de duas praias morfodinamicamente distintas. Os setores de cada praia foram analisados levando em consideração aspectos morfodinâmicos, antrópicos (atividades recreativas) e ecológicos. Morfodinamicamente, uma das praias apresentou sedimentos formados por areia fina, suave inclinação e morfodinamismo com características dissipativas. A outra praia apresentou sedimentos formados por areia média, perfil íngreme e características morfodinâmicas entre intermediárias a refletivas. Em ambas as praias, durante o verão, o setor urbanizado apresentou maior abundância de usuários do que o setor não urbanizado. Na praia com morfodinamismo dissipativo, relações negativas foram observadas entre a abundância de usuários e a dos organismos Bledius bonariensis, Donax hanleyanus, Thoracophelia furcifera, Excirolana armata, Phoxocephalopsis sp. e Tholozodium rhombofrontalis. Já na praia com morfodinamismo intermediário a refletivo, foram registradas baixas abundâncias de Atlantorchestoidea brasiliensis e Excirolana braziliensis no setor urbanizado. Assim, os resultados do presente estudo sugerem a utilização de algumas espécies como indicadores de impactos antrópicos nos ecossistemas praiais.

Descriptors: Sandy beaches, Morphodynamics, Macroinfauna, Recreational activity.

Descritores: Praias arenosas, Morfodinâmica, Macroinfauna, Atividade recreativa.

\section{INTRODUCTION}

Sandy beaches are physically defined in terms of three key variables: sediment grain size and wave and tidal regimes (SHORT, 1996). The interaction between these factors produces a spectrum of morphodynamic beach types ranging from reflective beaches under a microtidal regime (narrow beaches with steep slopes) to dissipative beaches under a macrotidal regime (wide beaches with gentle slope) (SHORT, 1999).

Despite their deserted appearance, the intertidal regions of sandy beaches provide habitats for diverse populations of bacteria, diatoms and 
invertebrates such as polychaetes, molluscs and crustaceans. These organisms play important roles in beaches' ecological functioning as primary producers (diatoms), decomposers (bacteria), primary consumers (heterotrophic bacteria, part of the meiobenthos, suspensivore and herbivore macrobenthic organisms) and secondary consumers (another part of the meiobenthos, carnivorous macrobenthic organisms) (KNOX, 2000). The main predators in these systems include mainly fish and birds, which feed on all trophic levels (DUGAN et al., 2003). Thus, sandy beaches are considered key ecosystems both for sea and continent, since they play their part in the energy transfer between these environments (GHESKIERE et al., 2005).

According to Defeo et al. (2009), the composition and abundance of the macrobenthic communities of sandy beaches are controlled primarily by the physical environment, intertidal swash and sediment characteristics, and these factors are harsher on reflective than dissipative beaches. The Autoecological Hypothesis (AH) (NOY-MEIR, 1979) postulates that in physically controlled environments, communities are but little influenced by interspecific relationships, each species responding independently to the environmental factors. Thus the ecological diversity, species richness, abundance and biomass of macrobenthic communities show a clear pattern, with a tendency to increase these parameters from reflective conditions toward the dissipative stage (MCLACHLAN; DORVLO, 2005; MCLACHLAN; BROWN, 2006).

Changes in the composition of beach macrobenthic communities are also to be expected along the gradient of exposure, with crustaceans predominating on reflective beaches, while polychaetes, more sensitive to exposure to waves and coarse sediments, dominating on most dissipative beaches (DEFEO; MCLACHLAN, 2005; DEFEO et al., 2009).

In addition to physical factors, there are also biological factors that structure macrobenthic communities of sandy beaches. On reflective beaches the effects of biological interactions may be masked by physical factors; however, these interactions (intra and interspecific competition and predation) clearly influence the structuring of communities on dissipative beaches (KNOX, 2000; DEFEO; MCLACHLAN, 2005).

Most studies conducted on sandy beaches seek to associate spatial and temporal variations that occur in the macrobenthic communities and populations with environmental parameters and/or biological processes (BORZONE et al., 1996; BORZONE; SOUZA, 1997; SOUZA; BORZONE, 2000; BARROS et al., 2001; SOUZA; BORZONE, 2007; ALVES; PEZZUTO, 2009). Few studies aim to assess the consequences of human disturbances on population processes and community structure on sandy beaches (LERCARI; DEFEO, 2003).

In Brazil, although there are still many vacant beaches, real estate speculation has intensified in recent decades, reaching alarming levels. Some studies to evaluate the impact of this uncontrolled development associated with tourism on the macrobenthic species have been conducted. In Rio de Janeiro, the impacts on the population size of the talitrid amphipods Atlantorchestoidea brasiliensis and the isopod Excirolana braziliensis have been related to the high degree of urbanization (VELOSO et al., 2006; 2008; 2009; 2011). Low densities of Ocypode quadrata on beaches with a high degree of human impact have also been reported by other authors on the coast of Pernambuco (SOUZA et al., 2008), Bahia (MAGALHÃES et al., 2009), Espírito Santo (ARAUJO et al., 2008), Santa Catarina (BLANKENSTEYN, 2006) and Rio Grande do Sul (NEVES; BENVENUTI, 2006).

Despite the increasing interest in addressing this issue, most research has sought to evaluate the effects of human disturbances at the population level, the need for approaches that consider the whole macrobenthic community being evident. Additionally, anthropogenic interference should be considered carefully, the different intensities and frequencies of impact beyond the recreational patterns, which vary from place to place, being taken into account (VELOSO et al., 2008). This study aimed to study and compare the effect of human recreational activities on the abundance and richness of macrofauna of dissipative and reflective sandy beaches.

\section{Material And Methods}

\section{Sampling and Laboratory Procedures}

The study was conducted on two sandy beaches of the south coast of Brazil: Shangri-lá beach (Paraná State) and Barra do Sul beach (Santa Catarina State) (Fig. 1). On each beach, two nearby sectors (each $50 \mathrm{~m}$ long) on the same shoreline were chosen: a non-urbanized sector lacking infrastructure and an urbanized sector, which presented major infrastructure items (houses, buildings and parking nearby, shelters for lifeguards and garbage bins on the beach) and was frequented by street vendors.

On Shangri-lá, where the sectors are separated by a distance of about $1.5 \mathrm{~km}$, the nonurbanized one has a large strip of vegetation of about $500 \mathrm{~m}$ on the backshore, in width by contrast, the urbanized sector presents a narrow strip (70 m wide), on which much of the natural vegetation has been replaced by gardens, driveways and parking spaces. During the high season (summer) in the urbanized 
sector, the "Operação Viva Verão", which involves the pitching of tents for supervised recreational activities and daily beach cleaning, is held. On Barra do Sul the sectors are $3 \mathrm{~km}$ apart, the non-urbanized has a backshore with a $90 \mathrm{~m}$ wide strip covered with vegetation and dunes, while the urbanized one has no dunes or vegetation. .

The sampling of the benthic macroinvertebrates was undertaken at low tide on two occasions corresponding to periods of intense recreational activity, the first in summer (25 February - 1 March, 2009, one week after the summer holiday period and Carnival) and in winter (4 - 8 August, 2009 , one week after the school holiday period).

In each sector six transects, perpendicular to the waterline, were established at random. Each transect was divided into 10 equidistant levels from the drift line (point 1) up to the waterline (point 10). The use of equidistant levels permits the distribution of sampling in equivalent level zones regardless of the total width of each beach, which varies from 59 to 110 $\mathrm{m}$ on Shangri-lá and from 23 to $40 \mathrm{~m}$ on Barra do Sul. Samples were taken from each level with the aid of a $0.05 \mathrm{~m}^{2}$ cylinder buried to $20 \mathrm{~cm}$ depth, then they were washed on a $500 \mu \mathrm{m}$ mesh and preserved in $10 \%$ neutralized formalin while still in the field. Then the organisms were sorted, identified and counted in the laboratory.

As a measure of the intensity of the recreational activity undertaken (impact) in each sector, a survey of the number of users along a $50 \mathrm{~m}$ long stretch multiplied by the total width of the beach profile was performed. The count was made every 30 minutes for 5 consecutive hours (between 9:00 and $14: 00)$ in the summer ( 5 counts) and winter ( 4 counts) holiday seasons.

\section{Physical Characterization}

For grain size characterization on the sectors of each beach, a sediment sample was collected at each level with the use of plastic pots $(300 \mathrm{ml})$ on only one transect. In the laboratory, samples were dried at $60^{\circ} \mathrm{C}$ and the sediment was sieved with half phi interval sieves ( $\mathrm{phi}=-\log _{2}$ diameter $\mathrm{mm}$ ) (SUGUIO, 1973) to determine mean grain diameter and other statistical parameters of the sediment (degree of selection, asymmetry and kurtosis) (FOLK; WARD, 1957).

On days of macrofauna sampling, the slope of each sector was measured with the aid of an optical sight. The wave height was estimated visually by the same observer. The wave period was estimated with the aid of a stopwatch and corresponded to $1 / 10$ of the total time elapsed for the passage of eleven consecutive crests at a fixed point in the surf zone. These measurements were used in a morphodynamic state calculation: $\Omega=\mathrm{Hb} / \mathrm{Ws} * \mathrm{~T}$ where $\mathrm{Hb}$ is the wave height $(\mathrm{cm})$, Ws the sediment settling velocity $\left(\mathrm{cm} . \mathrm{s}^{-1}\right)$ and $\mathrm{T}$ is the wave period (s) (DEAN, 1973).

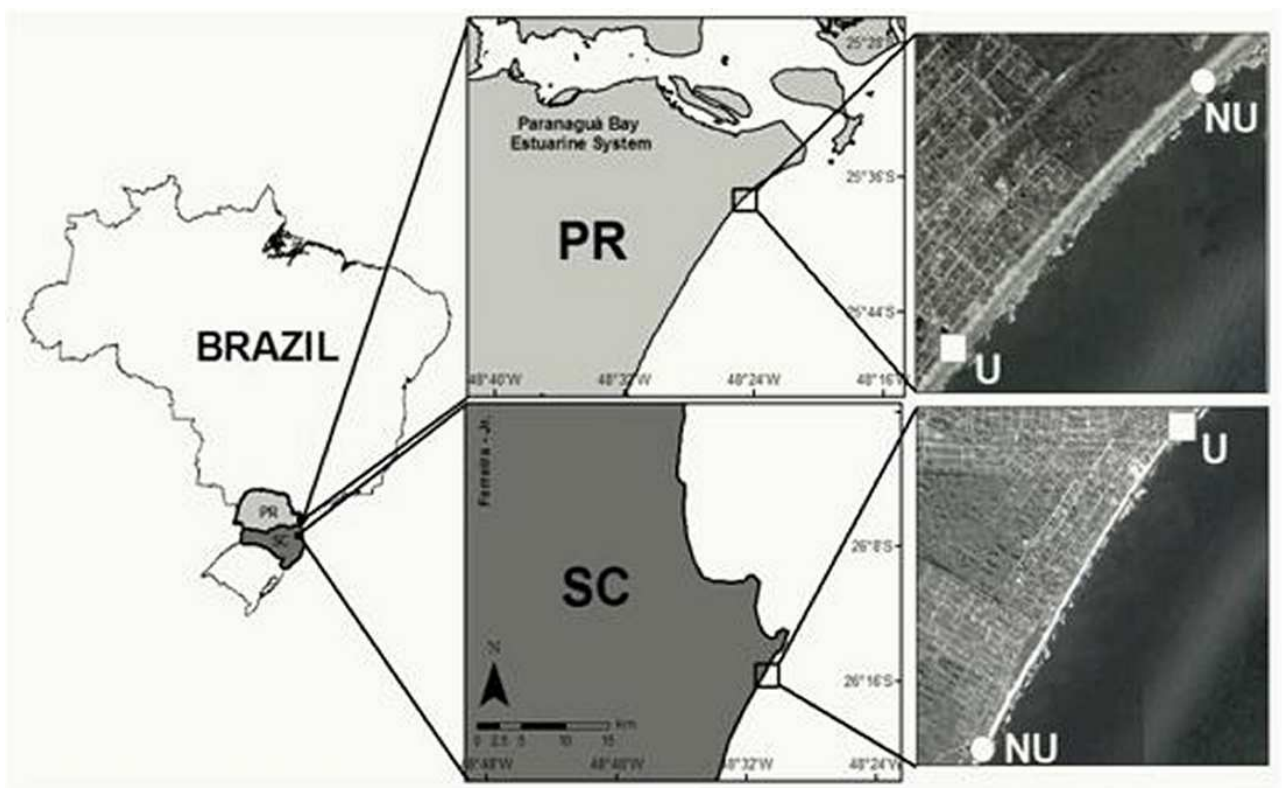

Fig. 1. Location of non-urbanized (NU) and urbanized (U) sectors of beaches: Shangri-lá (PR) (above) and Barra do Sul (SC) (below). 
Statistical Analysis

The data from Shangri-lá and Barra do Sul beaches were analyzed separately. To compare the abundance of users between the non-urbanized and urbanized sectors Student's-t test was performed for each sampling season (summer and winter). Prior to the biotic data analysis, linear abundance (ind. $\mathrm{m}^{-1}$ ) of each macrofauna species was calculated for each of the six transects. Constancy criteria (present in more than six samples) and relative frequency (> $20 \%$ of total sampled individuals) were used to selected the most representative species. To compare the biotic parameters (total linear abundance, total number of species and linear abundance of selected species) of benthic macrofauna between sectors, Student's-t test was applied for each season separately. The normality and homogeneity of users and macrobenthic species abundance data were verified using the tests of Kolmogorov-Smirnov and Levene (UNDERWOOD, 1997), respectively. When these assumptions were not met, the following order of transformation was tested: $\log (x+1)$ and square root to reduce the heterogeneity of variances.

To compare the macrofauna composition between sectors a matrix was constructed with data from the linear abundance of selected species for each sampling season. This matrix of biological data was ordered (nMDS) using Bray-Curtis's similarity index (CLARKE; WARWICK, 1994). The PERMANOVA test (ANDERSON, 2005) was conducted in order to assess the possible differences in faunal composition between sectors observed in exploratory multivariate analysis (nMDS).

\section{RESULTS}

On Shangri-lá beach, the sectors showed very similar morphological and sedimentary characteristics in both sampling seasons. The profiles were long and with a gentle slope (Fig. 2A), the sediment was mainly composed of fine sand ( 3 to 2 phi), well sorted, approximately symmetrical, and of mesokurtic distribution. Regardless of the season, both sectors were morphodynamically classified as dissipative (Table 1).

On Barra do Sul beach, the sectors presented a narrow, steep beach profile in both seasons (Fig. 2B). The sediment was composed of medium sand (2 to $1 \mathrm{phi}$ ), with greater values in the urbanized sector (> 1.6 phi), selection and kurtosis were quite similar between sectors, with moderately selected grains and mesokurtic distribution. However, these sectors differed in two respects: sediment asymmetry and morphodynamic state, the non-urbanized sector had sediments with positive asymmetry and reflective morphodynamism, while the urbanized sector had approximately symmetrical sediments and was classified as of intermediate morphodynamic state (Table 1).
A

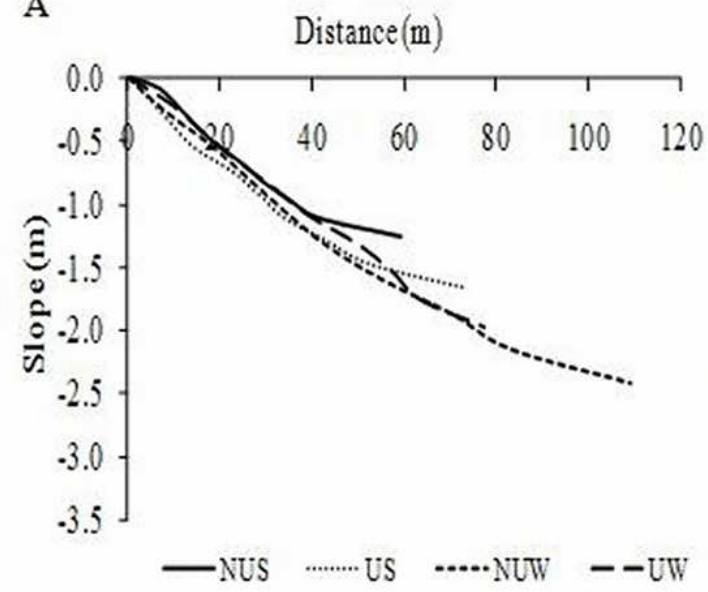

B

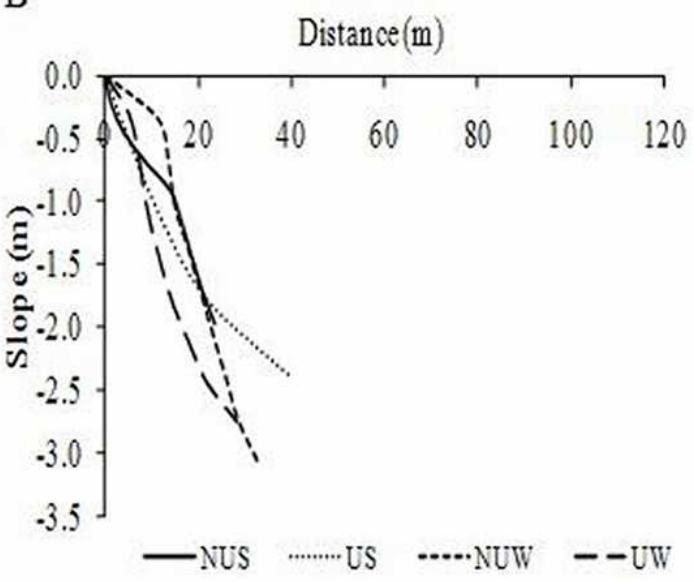

Fig. 2. Shore profiles of the Shangri-lá (A) and Barra do Sul (B) beaches: non-urbanized sector - summer (NUS), urbanized sector - summer (US), non-urbanized sector - winter (NUW), urbanized sector - winter (UW). 
Table 1. Sediment (DM - mean diameter; SEL - selection; ASS - asymmetry and CUR - sediment kurtosis) and morphodynamic (Hb - wave height; $\mathrm{T}$ - wave period; Ws - sediment settling velocity and $\Omega$ - Omega Dean) parameters of non-urbanized (NU) and urbanized (U) sectors of Shangri-lá and Barra do Sul beaches.

\begin{tabular}{|c|c|c|c|c|c|c|c|c|}
\hline & \multicolumn{4}{|c|}{ _Shangri-lá_ } & \multicolumn{4}{|c|}{ Barra do Sul } \\
\hline & \multicolumn{2}{|c|}{ Summer } & \multicolumn{2}{|c|}{ Winter } & \multicolumn{2}{|c|}{ Summer } & \multicolumn{2}{|c|}{ Winter } \\
\hline & NU & $\mathbf{U}$ & $\mathbf{N U}$ & $\mathbf{U}$ & NU & $\mathbf{U}$ & NU & $\mathbf{U}$ \\
\hline DM (Ф) & $2.90( \pm 0.02)$ & $2.60( \pm 0.12)$ & $2.60( \pm 0.07)$ & $2.70( \pm 0.07)$ & $1.21( \pm 0.05)$ & $1.71( \pm 0.04)$ & $1.2( \pm 0.03)$ & $1.37( \pm 0.06)$ \\
\hline SEL (Ф) & $0.38( \pm 0.01)$ & $0.44( \pm 0.02)$ & $0.49( \pm 0.02)$ & $0.45( \pm 0.02)$ & $0.54( \pm 0.01)$ & $0.51( \pm 0.01)$ & $0.55( \pm 0.02)$ & $0.52( \pm 0.01)$ \\
\hline $\operatorname{ASS}(\boldsymbol{\Phi})$ & $-0.04( \pm 0.03)$ & $0.02( \pm 0.02)$ & $-0.05( \pm 0.02)$ & $-0.04( \pm 0.02)$ & $0.16( \pm 0.02)$ & $0.05( \pm 0.02)$ & $0.15( \pm 0.02)$ & $0.09( \pm 0.02)$ \\
\hline CUR (Ф) & $0.88( \pm 0.02)$ & $0.97( \pm 0.02)$ & $1.01( \pm 0.02)$ & $0.96( \pm 0.02)$ & $0.96( \pm 0.02)$ & $0.92( \pm 0.02)$ & $0.92( \pm 0.02)$ & $0.94( \pm 0.01)$ \\
\hline $\mathrm{Hb}(\mathrm{cm})$ & 110 & 110 & 150 & 180 & 110 & 120 & 70 & 100 \\
\hline $\mathbf{T}(\mathrm{s})$ & 10 & 9 & 11 & 11 & 11 & 11 & 8 & 7 \\
\hline Ws $(\mathrm{cm} / \mathrm{s})$ & 1.39 & 1.91 & 1.91 & 1.72 & 6.38 & 4.37 & 6.38 & 5.45 \\
\hline $\mathbf{\Omega}$ & 7.89 & 6.41 & 7.15 & 9.49 & 1.57 & 2.55 & 1.37 & 2.48 \\
\hline
\end{tabular}

On Shangri-lá beach a highly significant difference was detected in users' abundance between sectors in the summer $(t=-13.62, p=0.000001)$, the urbanized sector having the highest number of users (Fig. 3A). In the survey conducted during the winter, with few users, there was no difference in users' abundance between sectors $(t=-2.27, p=0.0638)$ (Fig. 3B). On Barra do Sul beach, users' abundance followed the same pattern as that of Shangri-lá. In summer, the urbanized sector had significantly higher abundance than did the non-urbanized sector $(t=$ 5.85, $p=0.0004$ ) (Fig. 4A); however, there were no significant differences between sectors $(t=-0.04, p=$ 0.9683 ) for the counts undertaken in winter (Fig. 4B).

On Shangri-lá beach mean values of total abundance and total number of benthic macrofauna species were only significantly higher in the nonurbanized sector in summer (Table 2).

The taxa Donax hanleyanus, Thoracophelia

furcifera, Excirolana armata, Tholozodium rhombofrontalis and Phoxocephalopsis sp. accounted for this difference in abundance. The insect Bledius bonariensis was only present in the nonurbanized sector in the summer sampling (Table 2).
A

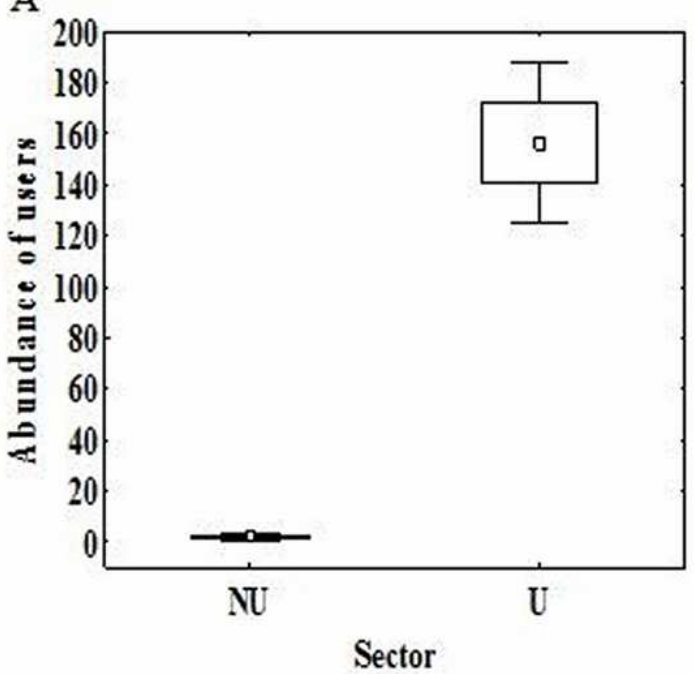

B

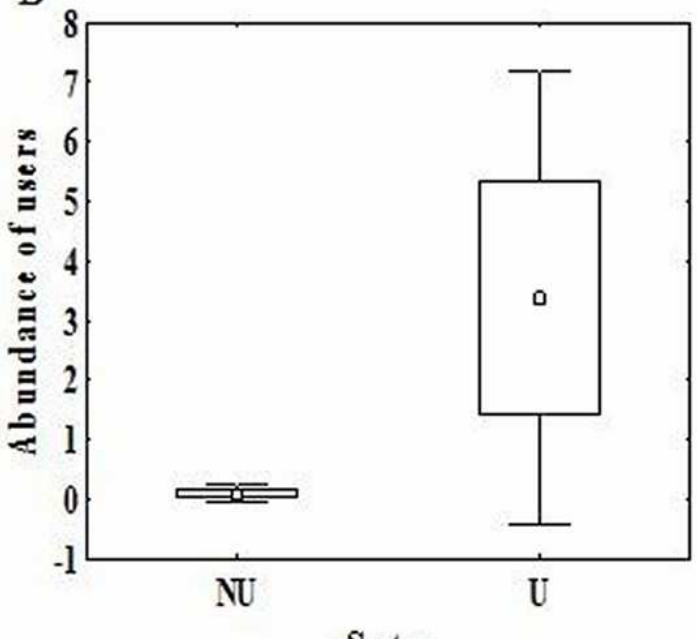

Sector

Fig. 3. Users' average abundance ( \pm error and standard deviation) in each sector (NU - non-urbanized and U - urbanized) recorded on the Shangri-lá beach during summer (A) and winter (B) survey. 
A

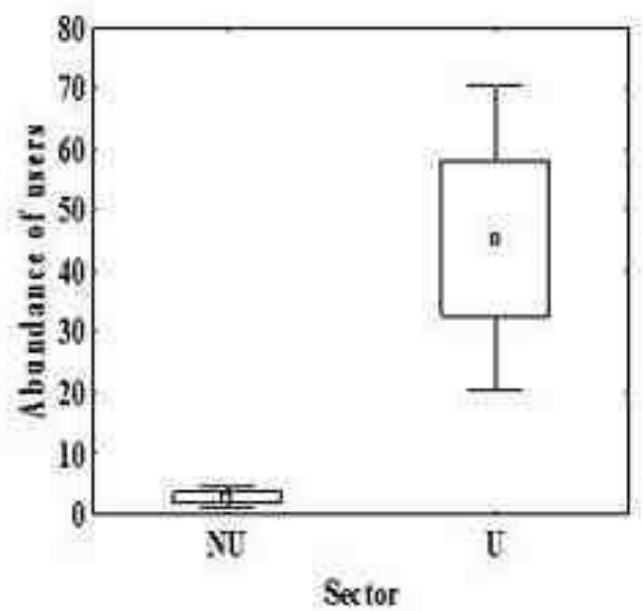

B

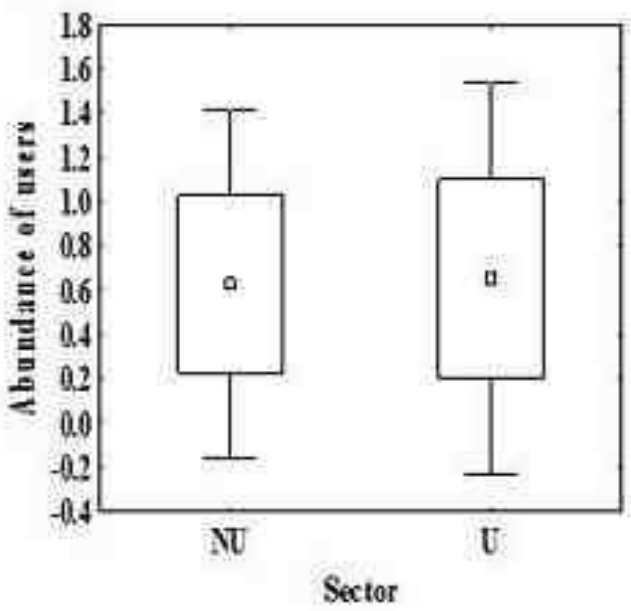

Fig. 4. Users' average abundance ( \pm error and standard deviation) in each sector (NU - non-urbanized and U - urbanized) recorded on Barra do Sul beach during summer (A) and winter (B) survey.

Table 2. Linear abundance average values $( \pm$ SE) and values of Student's-t test performed to compare the abundance of total macrofauna and selected species and the total number of species between the non-urbanized (NU) and urbanized (U) sectors of the Shangri-lá beach. $p$ values: $*<0.05, * *<0.01, * * *<0.001$

\begin{tabular}{|c|c|c|c|c|c|c|}
\hline \multirow[b]{2}{*}{ Taxa } & \multicolumn{3}{|c|}{ Summer } & \multicolumn{2}{|c|}{ _Winter } & \multirow[b]{2}{*}{$t$} \\
\hline & NU & $\mathbf{U}$ & $t$ & NU & $\mathbf{U}$ & \\
\hline \multicolumn{7}{|l|}{ Polychaeta } \\
\hline Thoracophelia furcifera & $9677.6( \pm 2082.2)$ & $2857.9( \pm 1328.5)$ & $2.76^{*}$ & $35581.7( \pm 3452.5)$ & $10694.0( \pm 2507.1)$ & $5.83^{* * *}$ \\
\hline Hemipodus olivieri & - & $70.0( \pm 44.3)$ & - & $749.5( \pm 305.3)$ & $299.3( \pm 89.1)$ & ns \\
\hline Scolelepis goodybodyi & $64739.4( \pm 8311.9)$ & $57233.0( \pm 3986.1)$ & ns & $232532.5( \pm 45800.1)$ & $150661.5( \pm 67384.2)$ & ns \\
\hline \multicolumn{7}{|l|}{ Mollusca } \\
\hline Donax gemmula & - & - & - & $5232.8( \pm 1535.2)$ & $1075.3( \pm 238.7)$ & $3.30 * *$ \\
\hline Donax hanleyanus & $1361.3( \pm 327.6)$ & $210.4( \pm 108.5)$ & $3.5^{* *}$ & $1505.7( \pm 1422.4)$ & $16460.5( \pm 4464.5)$ & $3.93 * *$ \\
\hline \multicolumn{7}{|l|}{ Crustacea } \\
\hline Bathyporeiapus sp. & $232.7( \pm 111.6)$ & $35.0( \pm 35.0)$ & ns & $9587.2( \pm 1021.3)$ & $1746.0( \pm 881.2)$ & $5.81^{* * *}$ \\
\hline Excirolana armata & $10333.0( \pm 1827.7)$ & $3495.0( \pm 638.2)$ & $3.53 * *$ & $6773.8( \pm 1281.2)$ & $8370.5( \pm 529.6)$ & ns \\
\hline Phoxocephalopsis sp. & $3671.5( \pm 1273.6)$ & $110.9( \pm 53.4)$ & $2.80 *$ & $7132.2( \pm 743.9)$ & $814.2( \pm 232.3)$ & $9.26 * * *$ \\
\hline Tholozodium rhombofrontalis & $4597.5( \pm 876.6)$ & $108.9( \pm 39.8)$ & $9.15^{* * *}$ & $2044.0( \pm 633.8)$ & $959.8( \pm 146.1)$ & ns \\
\hline \multicolumn{7}{|l|}{ Insecta } \\
\hline Bledius bonariensis & $885.7( \pm 212.6)$ & - & - & $80.0( \pm 50.6)$ & $593.3( \pm 196.8)$ & $3.26 * *$ \\
\hline Insecta (larva não identificada) & $166.8( \pm 30.8)$ & $21.6( \pm 21.6)$ & $3.87 * *$ & $240.0( \pm 240.0)$ & $421.3( \pm 151.0)$ & ns \\
\hline Total abundance & $95822.2( \pm 8890.7)$ & $64361.6( \pm 3922.6)$ & $3.24 * *$ & $302534.3( \pm 48514.9)$ & $192235.3( \pm 67428.0)$ & $\mathrm{ns}$ \\
\hline Number of species & $9.5( \pm 0.5)$ & $6.2( \pm 0.3)$ & $5.70^{* * *}$ & $11.3( \pm 0.8)$ & $11.5( \pm 0.2)$ & ns \\
\hline
\end{tabular}

In winter, total abundance and number of species values were similar between sectors, however significant differences occurred in the abundances of six species. Bathyporeiapus sp., Donax gemmula, T. furcifera and Phoxocephalopsis sp. presented greater abundance in the non-urbanized sector, while $B$. bonariensis and $D$. hanleyanus were more abundant in the urbanized sector (Table 2). The graphical representation of the multivariate analysis showed a clear spatial separation of non-urbanized and urbanized sectors in both sampling seasons (Fig. 5A and B), confirmed by the results obtained by PERMANOVA (Table 3). 


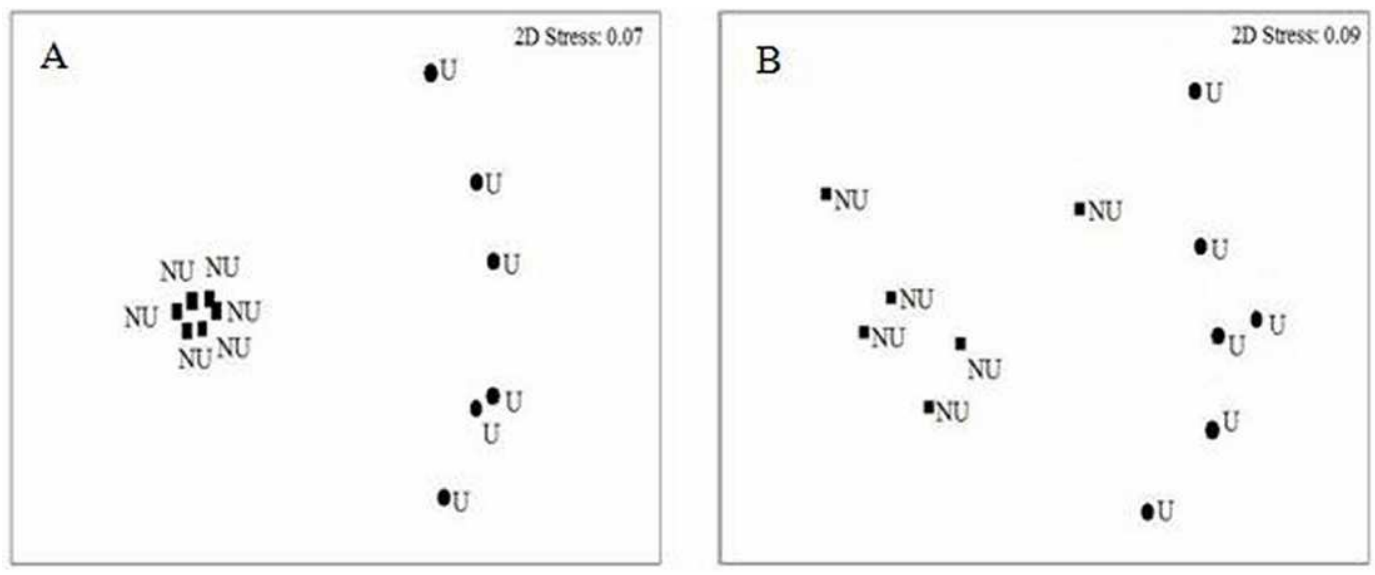

Fig. 5. n-MDS ordination results of a similarity matrix (Bray-Curtis) obtained from the linear abundance of benthic macrofauna of non-urbanized (NU) and urbanized (U) sectors of the Shangri-lá beach during summer (A) and winter (B) season. Data transformed by $\log (x+1)$.

Table 3. Results of the PERMANOVA analysis for benthic macrofauna comparing non-urbanized and urbanized sectors of the Shangri-lá beach. (df) degrees of freedom, (MQ) mean squares, $p$ (MC) Monte Carlo permutation significance.

\begin{tabular}{|c|c|c|c|c|c|c|c|c|c|}
\hline & \multicolumn{5}{|c|}{ _Summer_ } & \multicolumn{4}{|c|}{ _Winter } \\
\hline & df & MQ & $\boldsymbol{F}$ & $p$ & $p($ MC) & MQ & $F$ & $p$ & $p(\mathbf{M C})$ \\
\hline Sector & 1 & 2143.7854 & 12.755 & 0.0032 & 0.0001 & 415.297 & 10.985 & 0.0032 & 0.0007 \\
\hline Residue & 21 & 168.0669 & & & & 37.8047 & & & \\
\hline
\end{tabular}

On Barra do Sul beach values for total abundance of macrofauna were also only significantly higher in the non-urbanized than in the urbanized

sector during the summer season, but the total number of species was not significantly different between sectors in the two sampling periods (Table 4).

Table 4. Linear abundance average values $( \pm$ SE) and values of the Student's-t test performed to compare the total macrofauna abundance and selected species and the total number of species between the non-urbanized $(\mathrm{NU})$ and urbanized (U) sectors from Barra do Sul beach. $p$ values: $*<0.05, * *<0.01, * * *<0.001$.

\begin{tabular}{|c|c|c|c|c|c|c|}
\hline \multirow[b]{2}{*}{ Taxa } & \multicolumn{2}{|c|}{ _Summer } & \multirow[b]{2}{*}{$t$} & \multicolumn{2}{|c|}{ Winter } & \multirow[b]{2}{*}{$t$} \\
\hline & NU & $\mathbf{U}$ & & NU & $\mathbf{U}$ & \\
\hline \multicolumn{7}{|l|}{ Polychaeta } \\
\hline Hemipodus olivieri & $29.5( \pm 15.6)$ & $190.9( \pm 42.7)$ & $3.55^{* *}$ & $18.0( \pm 11.4)$ & $33.7( \pm 21.3)$ & ns \\
\hline Psionidens sp. & $428.7( \pm 67.8)$ & $369.55( \pm 123.7)$ & ns & $42.0( \pm 19.0)$ & $80.8( \pm 50.8)$ & $\mathrm{ns}$ \\
\hline \multicolumn{7}{|l|}{ Mollusca } \\
\hline Donax hanleyanus & $171.0( \pm 40.7)$ & $288.7( \pm 38.0)$ & ns & $173.5( \pm 86.1)$ & $190.7( \pm 48.1)$ & ns \\
\hline \multicolumn{7}{|l|}{ Crustacea } \\
\hline Antlantorchestoidea brasiliensis & $120.3( \pm 59.3)$ & $13.3( \pm 9.2)$ & ns & $167.3( \pm 40.4)$ & $11.7( \pm 11.7)$ & $3.70^{* * *}$ \\
\hline Emerita brasiliensis & $32.1( \pm 11.6)$ & $44.3( \pm 28.0)$ & $\mathrm{ns}$ & $613.8( \pm 465.3)$ & $204.2( \pm 105.0)$ & $\mathrm{ns}$ \\
\hline Excirolana brazilienzis & $9201.3( \pm 751.1)$ & $6408.8( \pm 699.4)$ & $2.72 *$ & $1699.3( \pm 283.1)$ & $1837.5( \pm 386.1)$ & $\mathrm{ns}$ \\
\hline Total abundance & $10017.9( \pm 787.7)$ & 7333.5 & $2.36^{*}$ & $2764.7( \pm 683.4)$ & $2418.3( \pm 502.5)$ & ns \\
\hline Number of species & $5.2( \pm 0.7)$ & $4.8( \pm 0.4)$ & ns & $5.3( \pm 0.6)$ & $4.3( \pm 0.8)$ & $\mathrm{ns}$ \\
\hline
\end{tabular}


Differences in abundances were related to significantly higher abundances of Excirolana braziliensis in the non-urbanized sector in summer. The amphipod Atlantorchestoidea brasiliensis always showed higher abundances in the non-urbanized sector, although the difference was significant only in winter. The polychaete Hemipodus olivieri showed an inverse pattern, with significantly higher abundance in the urbanized sector in summer (Table 4).

Dissimilarity between the non-urbanized and urbanized sectors was only observed during the ordination analysis in the summer sampling (Fig. 6A and B), this result was confirmed by the PERMANOVA (Table 5).

\section{Discussion}

The beaches studied are good examples of extreme morphodynamic stages, with the Shangri-lá beach in the dissipative stage (wide and flat shoreface, fine sand) and the Barra do Sul beach in the intermediate to reflective stage (narrow and steep shoreface, medium sand). The sectors of the Shangrilá beach were considered morphodynamically similar and with little variation between seasons. A nearby

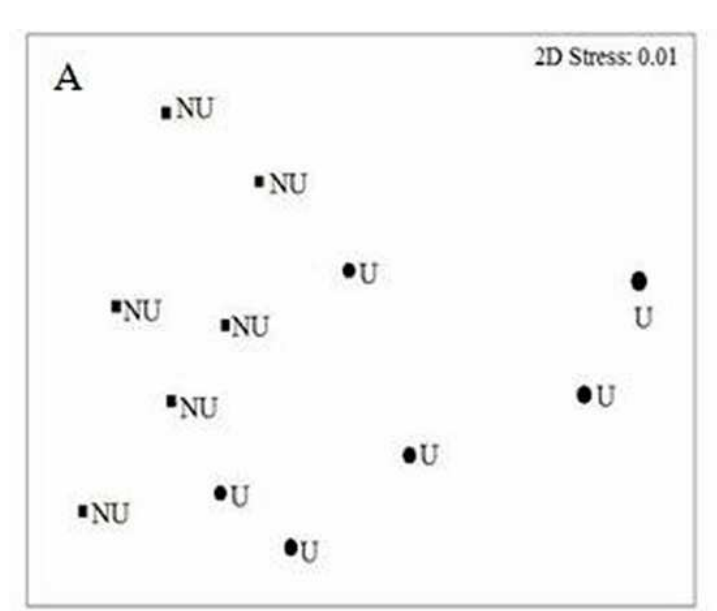

location on the same shoreline explains this similarity, and restricts its differences to the degree of urbanization and, as a consequence, to the intensity of the recreational activities practiced. Comparisons between nearby sites on the same shoreline reduce the influence of natural environmental factors, in spite of the variations in these parameters along the beach profile (VELOSO et al., 2009).

Barra do Sul beach showed some sedimentary and morphodynamic variations between the sectors. In both seasons, the non-urbanized sector showed a reflective stage with medium sand; however, the urbanized sector was classified as of intermediate stage, and the sediment had smaller sand grains (> 1.6 phi) than the other sector. The physical differences found between the sectors may be related to the proximity of the urbanized sector to the secondary axis of the Babitonga Bay (NE - SW), where the Linguado Channel is located. The contribution of fine sediments originating from this channel and the instability in the balance and sediment transport and changes in drainage patterns caused by the removal of the vegetation and the dunes in the urbanized sector may explain these differences.

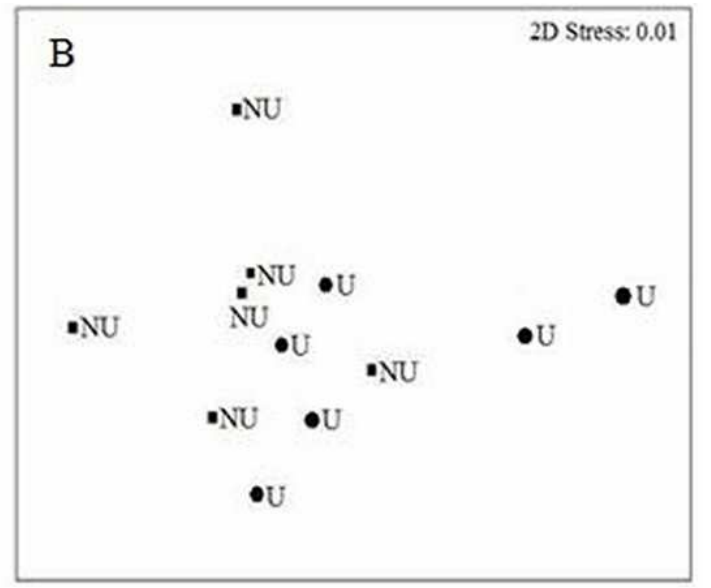

Fig. 6. n-MDS ordination results of a similarity matrix (Bray-Curtis) obtained from the linear abundance of benthic macrofauna of non-urbanized (NU) and urbanized (U) sectors of the Barra do Sul beach during the summer (A) and winter (B) season. Data transformed by square root.

Table 5. Results of the PERMANOVA analysis for the benthic macrofauna comparing non-urbanized and urbanized sectors of Barra do Sul beach. (df) degrees of freedom, (MQ) mean squares, $p$ (MC) Monte Carlo permutation significance.

\begin{tabular}{|c|c|c|c|c|c|c|c|c|c|}
\hline \multirow{2}{*}{\multicolumn{2}{|c|}{ df }} & \multicolumn{4}{|c|}{ Summer_ } & \multicolumn{4}{|c|}{ _Winter_ } \\
\hline & & MQ & $F$ & $p$ & $p($ MC) & MQ & & $p$ & $p(\mathrm{MC})$ \\
\hline Sector & 1 & 702.7650 & 5 & 0.0032 & 0.0075 & 963.561 & 1.730 & 0.1923 & 0.1625 \\
\hline Residue & 10 & 131.5590 & & & & 558.409 & & & \\
\hline
\end{tabular}


As had been expected, the intensity of recreational activities, quantified through the counting of the numbers of users, was greater in the urbanized sectors of both beaches. According to De Ruyck et al. (1997), the level of beaches' use is closely related to factors such as development, transportation and site popularity. In the light of such aspects, the discrepancy in the intensity of recreational activities between sectors can easily be understood. Thus, the means of access to the urbanized area presented by both beaches in the form of paved streets as well as in terms of the infrastructure provided for tourists (restaurants, parking facilities, vacation homes, life-saving personnel, street vendors) deserve to be emphasized.

The urbanized sectors were more visited during summer than winter, in contrast with the nonurbanized sectors that received a low number of visitors in both seasons. The decline in visitor numbers during winter contrasts with the related pattern on southeastern Brazilian beaches which continue to receive a high density of bathers during winter and thus continue to be subject to high-intensity impact all year round (VELOSO et al., 2006; 2008; 2009). In Shangri-lá's urbanized sector, the "Operação Viva Verão" is undertaken during the summer season and offers tourists a variety of supervised recreational activities (aerobics, dancing, soccer, volleyball) and results in the consequent clustering of users in this location.

Users' abundance registered in the urbanized sector of the Shangri-lá beach (average: 188 people) was 2.24 times higher than that recorded on the Barra do Sul beach (average: 84 people), indicating a greater intensity of trampling impact on the former beach. Despite the difference in the number of users between the beaches studied, the impact can be considered equivalent given that Shangri-lá also has more than twice the shoreface width (average: $80 \mathrm{~m}$ ) as Barra do Sul (average: $30 \mathrm{~m}$ ). However, beaches differ in the types and intensity of recreational activities practiced by their users. On Shangri-lá a wide variety of recreational activities was observed (running, walking, racquetball, volleyball, soccer), but on Barra do Sul the most frequent activity was the slight displacement of swimmers parallel and perpendicular to the waterline (personal observation).

The results of this study provide evidence that the disturbance caused by recreational activities affects the composition and structure of the macrobenthic community on Shangri-lá beach, with significant reductions in both the number of species and total abundance in the urbanized sector. Although the sectors of Barra do Sul beach presented variation in sediment composition and morphodynamic stage, such features were not considered the main factors responsible for the differences in the total abundance of macrofauna observed between the sectors. The clear trend to increasing richness and abundance of macrofauna on beaches composed of finer sediments, which exhibit less hostile conditions for the establishment of organisms (BROWN; MCLACHLAN, 2002), was not observed between the sectors on this beach. Contrary to this trend, the urbanized sector (dominated by local finer sediments) showed lower total abundance of organisms than the non-urbanized sector. It is noteworthy that this occurred only in summer, a period characterized by significant differences in user abundance across sectors, suggesting the negative influence of anthropogenic disturbance on the benthic macrofauna of this beach.

Changes in the macrobenthic community of both beaches studied were also evident on multivariate analysis, with the formation of two distinct groups, one of the replicates of the non-urbanized sector and the other of those from the urbanized sector. In Rio de Janeiro, Veloso et al. (2006) also found significant differences in the macrobenthic communities of intermediate and reflective beaches, noting low abundances on urbanized beaches. Moreover, Jaramillo et al. (1996) concluded that the presence of human beings produces no significant adverse effects on the macroinfauna of reflective beaches. However, this study evaluated only the abundances of crustaceans such as Emerita analoga and the isopods Excirolana hirsuticauda, Excirolana braziliensis and the amphipod Orchestoidea tuberculata. In addition, the authors stress that on dissipative beaches, the same situation as that of the Shangri-lá beach, human impacts should be analyzed with caution in view of the higher biodiversity found in these environments.

In this study the practice of recreational activities also proved to be unfavorable for some of the macrobenthic species analyzed. On Shangri-lá beach, this impact has affected the abundance of the taxa Bledius bonariensis, Donax hanleyanus, Thoracophelia furcifera, Excirolana armata, Phoxocephalopsis sp. and Tholozodium rhombofrontalis, while on Barra do Sul beach only two species (Atlantorchestoidea brasiliensis and Excirolana braziliensis) were vulnerable to the impact. The low number of affected species observed on the Barra do Sul beach when compared to that of Shangrilá is not related to human pressure but to the morphodynamic stage of the respective beach. According to Mclachlan and Dorvlo (2005), species richness tends to decrease from dissipative (Shangrilá) to reflective beaches (Barra do Sul).

The insect Bledius bonariensis was not registered in the urbanized sector of Shangri-lá during the summer; however, this organism presented high abundance in the non-urbanized sector. By contrast, in winter, this species was present in both sectors. The disappearance of $B$. bonariensis may be associated 
with the cleaning process, which consists of the removal of garbage along with the natural debris deposited by the tide on the upper beach, typically inhabited by beetle species belonging to the genus Bledius (BORZONE; SOUZA, 1997; VELOSO et al., 1997; SCHREINER; OZORIO, 2003). The removal of debris in the urbanized sector has resulted in an unfavorable environment for this species' survival, with adults migrating elsewhere in search of food resources, since adult beetles are generally able to fly and thus quickly to establish new populations along the coast (LLEWELLYN; SHACKLEY, 1996).

Excirolana braziliensis on Barra do Sul beach and Tholozodium rhombofrontalis and Excirolana armata on Shangri-lá beach, only had a significantly higher abundance in the non-urbanized sector than in the urbanized sector in summer. These isopod species occupy the intermediate beach zones (SOUZA; GIANUCA, 1995; BORZONE et al., 1996; BORZONE; SOUZA, 1997) which are highly subject to the impact of recreational activities (games, walking, running and motor traffic) that were only recorded in the urbanized sectors of both beaches during the summer period. Isopods of the family Cirolanidae (e.g., Excirolana spp.) may be considered vulnerable to such impacts since they are ovoviviparous (without larval dispersal), therefore with juveniles recruiting in the same parental habitat (VELOSO et al., 2006). Moreover, these three species have thin exoskeletons, susceptible to the crushing or injuries from trampling associated with recreational activities.

In winter, these isopods showed similar abundances in both sectors, which could indicate the recovery of these species because of an existing period of minimal recreational impact during this season. Lozoya and Defeo (2006) claimed that peracarid populations under the effect of any disturbance redirect most of their energy to reproduction rather than somatic growth. Furthermore, on Brazilian beaches, E. braziliensis and E. armata have continuous reproduction (SOUZA, 1998,; CAETANO et al., 2006), a characteristic that could favor their recovery in the urbanized sectors during the winter.

Similarly to the results obtained for $E$. braziliensis in Barra do Sul, Veloso et al., (2006; 2011), on beaches of Rio de Janeiro, also found lower total densities of juveniles, males and females of this species on urbanized reflective beaches with higher numbers of users. In Barra da Tijuca, Veloso et al., (2011) highlight that human disturbance may be affecting the population of E. braziliensis: 1) directly, through human trampling and/or natural habitat jeopardizing, consequences of the great flux of visitors and urbanization, or 2) indirectly, by the isolation of individuals in the preserved stretch, located between environments subject to intense disturbance. Moreover, on reflective beaches on the Chilean coast, Jaramillo et al. (1996) observed no negative impact on the abundance of this species. According to Veloso et al. (2008), the low level of beach occupation studied by Jaramillo et al. (1996) may have generated misleading results. Additionally, the authors provided no data on the intensity of trampling or the characteristics of beach urbanization.

The amphipods Phoxocephalopsis sp. and Atlantorchestoidea brasiliensis recorded, respectively, on Shangri-lá and Barra Sul, showed lower abundances in the urbanized sector in both seasons. One factor analysis found no significant difference in the abundance of $A$. brasiliensis between sectors during the summer period due to the absence of this species in some replicates sampled in the nonurbanized sector. This fact may be related to sampling problems of the organism, since talitrids have a markedly patchy distribution and a jumping habit, making them difficult to sample. Nevertheless, the differences between the sectors were clear.

On southeastern Brazilian beaches, $A$. brasiliensis attains its highest density in both winter and summer, but a higher number of juveniles and ovigerous females appear in February (CARDOSO; VELOSO, 1996). The greatest frequency of users in summer coincides with the breeding season of this species. According to Veloso et al., (2009) this factor may increase the negative interaction during this period through the increase in mortality during their breeding season. Although winter conditions should allow the establishment of a dense talitrid population at urbanized sites, these areas have been so altered that the urbanized parts of the beaches can no longer support resident populations (VELOSO et al., 2008).

In the case of the genus Phoxocephalopsis, there is no other evidence regarding the vulnerability of these organisms in the face of human impacts; however, several authors have considered other species of amphipods such as Atlantorchestoidea brasiliensis and Talitrus saltator as bioindicators of anthropogenic and/or tourist activity (WESLAWSKI et al., 2000; NARDI et al., 2003; FANINI et al., 2005; VELOSO et al., 2006; UGOLINI et al., 2008; VELOSO et al., 2008, 2009). A. brasiliensis has several interesting features for an indicator species: direct development, distribution in intermediate and upper beach zones, surface burrowing in the sediment, easy visual identification and short life cycle (CARDOSO; VELOSO, 1996). Talitrids are jumper organisms that actively exploit the surface during low tide and due to this life strategy are probably more susceptible to impacts (VELOSO et al., 2009).

Density reductions in the amphipod $A$. brasiliensis and even the disappearance of the 
species have been described by Veloso et al. (2006; 2008 ; 2009) on urbanized reflective beaches with high levels of recreational activities. According to Fanini et al. (2005), the decrease in population size of $T$. saltator is more related to beach cleaning than to trampling from recreation. Changes in the morphological development of talitrid amphipods ( $T$. saltator) have been associated with human impacts. On the coast of Spain, Barca-Bravo et al. (2008) observed deformities in the bilateral symmetry of amphipods that inhabited beaches affected by greater tourist pressure. Human trampling and heavy tourist use are considered the main factors responsible for the direct or indirect mortality of $T$. saltator, considering that these activities can alter the degree of compacting of sediments and thus interfere with the movement of the organisms and consequently with their ability to escape (UGOLINI et al., 2008).

Comparisons between the sectors of the Shangri-lá beach indicated that the polychaete Thoracophelia furcifera does not tolerate any great intensity of recreational activities, even if they only occur during a restricted period of the year (summer). Even in winter, when there is less impact, abundances of these species in the urbanized sector remained low. The decline in population of $T$. furcifera in the urbanized sector could be related to natural fluctuations; however, Souza and Borzone (2007), on the Atami beach (4 km from Shangri-lá), indicated that the reproductive period of this species occurs from January to August (summer to winter). This species has characteristics that can aggravate the damage caused by human trampling such as rather rigid body structure, sedentary behavior, movement virtually restricted to the surface substrate excavation within the sediment, in addition to not having the habit of building tubes (typical structures of many polychaete species) which directly absorb any physical disturbance.

Among the species inhabiting the lower regions (swash or spreading zone) of sandy beaches, the filter feeder bivalve Donax hanleyanus showed a decrease in its abundance in the urbanized sector of the Shangri-lá beach during the summer, indicating a possible impact of recreational activities on the species. Moffett et al. (1998) found that other species of this genus (D. serra and D. sordidus) have different sensitivities according to the intensity of the trampling. These authors found that D. serra was slightly affected by all trampling intensities, while $D$. sordidus was affected only by high intensities. Further, in this study a second experiment was conducted with juveniles of $D$. serra, in which an increased number of individuals was observed to be injured due to the increase in trampling intensity.

In winter these donacid bivalves showed an inverse distribution pattern for Shangri-lá beach, with higher abundance in the urbanized sector, suggesting a probable recovery of this population. Individuals of the genus Donax are able to move into the subtidal zone (mareal migration), have high reproductive capacity and their larvae have greater power to disperse, thus allowing the recolonization of impacted areas (VELOSO et al., 2006).

Defeo and Alava (1995) related the fluctuations in density of $D$. hanleyanus on the Uruguayan coast to interspecific competition for food and space with Mesodesma mactroides. Cardoso and Veloso (2003) suggested that the same mechanism operates between $D$. hanleyanus and Emerita brasiliensis. This hypothesis has not been associated with the results obtained in this study since only one individual of $M$. mactroides was found during the two sampling periods and further, E. brasiliensis was absent. Temporal fluctuations in the abundance of $D$. hanleyanus can be attributed to recruitment events. The recruitment peaks occur during summer, autumn and winter on the southern coast of Brazil (CARDOSO; VELOSO, 2003) and in summer and autumn on the coast of Uruguay (DEFEO; ALAVA, 1995).

The amphipod Bathyporeiapus sp. and the bivalve Donax gemmula occurred in both sectors in winter sampling on Shangri-lá, but were more abundant in the non-urbanized sector. These species are a typical component of the subtidal zone of dissipative beaches (SOUZA; GIANUCA, 1995; BORZONE et al., 1996; BORZONE; SOUZA, 1997), but can extend their distribution to the intertidal zone (BORZONE et al., 1996). In the present study, there were no records of individuals of $D$. gemmula in the summer sampling, but differences in tidal level on the sampling day probably reduced the exposure of the subtidal zone (personal observation), thus affecting the accuracy of sampling, especially for these species.

Scolelepis goodbodyi dominated the macrobenthic community in both sectors of Shangri-lá beach. Polychaetes of the genus Scolelepis are typical and very abundant organisms on intertidal sandy beaches of Paraná (BORZONE et al., 1996; SOUZA; BORZONE, 2000; BARROS et al., 2001). This deposit filter feeder may be considered less vulnerable to the impacts assessed, as it inhabits the lower zone, subject to less recreational activity than the intermediate and upper zones of the beach. Another relevant aspect relates to its reproductive strategy. According to a study undertaken by MacCord and Amaral (2007), this species does not have enough space (small individuals) to produce a large number of eggs on a single occasion, so its reproduction is continuous. In tropical environments, the spawning of these organisms can occur over an extended period thereby increasing the probability of larval survival and success in recruitment. During investigations into 
the population dynamics of species on a dissipative beach of Paraná (Atami beach) Souza and Borzone (2000) identified a continuous breeding season with peak abundance in July and February. According to the authors, the intra-annual variation in abundance could be explained by the success in recruitment resulting from the observation of more than one cohort per year.

Although this study has not assessed the impact of freshwater discharge, this factor cannot be totally disregarded because at Shangri-lá heavy rainstorms cause intensive washing in the urbanized sector (personal observation) with a consequent considerable reduction in salinity. Lercari and Defeo (2003) analyzed the incidence of freshwater discharge on the macrobenthic community and found that the abundance, biomass and species richness significantly decreased towards the source of disturbance and were positively correlated with spatial variations in salinity.

We can conclude that intensive recreational activities together with urbanization in sectors of Shangri-lá and Barra do Sul beaches have led to such changes in the biota as loss of some species (Bledius bonariensis) as well as a considerable reduction in the abundances of others (Donax hanleyanus, Excirolana armata, Thoracophelia furcifera, Phoxocephalopsis sp. and Tholozodium rhombofrontalis on Shangri-lá and Atlantorchestoidea brasiliensis and Excirolana braziliensis on Barra do Sul). Thus this study suggests the use of these species as indicators of human impacts on sandy beaches as they provide potentially simple and economic tools for monitoring.

Although exposed sandy beaches represent some of the most extensive systems in the world, understanding the responses of communities subject to human disturbance is essential for proper management with a view to orderly environmental use and species conservation (LERCARI; DEFEO, 2003). According to Veloso et al. (2009), the effects of the environmental problems that threaten shore ecosystems can be minimized by means of conservation measures, such as a reduction of facilities and uses, control of the number of users, establishment of corridors and the prohibition of construction and motor traffic on beaches and dunes. Coastal management should focus on the sustainability of the system and ensure the maintenance of key processes such as sediment transport and the recycling of organic matter.

\section{ACKNOWLEDGEMENTS}

We wish to thank all those who participated in the fieldwork for their valuable efforts. We also thank the Center for Marine Studies (UFPR) and Benthology Laboratory (UNIVILLE) for providing the necessary infrastructure and the $\mathrm{CNPq}$ (National
Council for Scientific and Technological Development) and CAPES (Coordination for the Improvement of Higher Education Personnel) for their funding. Catarina N. S. Silva revised the english text.

\section{REFERENCES}

ALVES, E. S.; PEZZUTO, P. R. Effect of morphodynamics on annual average zonation pattern of benthic macrofauna of exposed sandy beaches in Santa Catarina, Brazil. Braz. J. Oceanogr., v. 57, n. 3, p. 189-203, 2009.

ANDERSON, M. J. Permanova: a FORTRAN computer program for permutational multivariate analysis of variance. Auckland: Department of Statistics, University of Auckland, New Zealand, 2005. 24 p.

ARAUJO, C. C. V.; ROSA, D. M.; FERNANDES, J. M. Densidade e distribuição espacial do caranguejo Ocypode quadrata (Fabricius, 1787) (Crustacea, Ocypodidae) em três praias arenosas do Espírito Santo, Brasil. Biotemas, v. 21, n. 4, p. 73-80, 2008.

BARCA-BRAVO, S.; SERVIA, M. J.; COBO, F.; GONZALEZ, M. A. The effect of human use of sandy beaches on developmental stability of Talitrus saltator (Montagu, 1808) (Crustacea, Amphipoda). A study on fluctuating asymmetry. Mar. Ecol., v. 29, n. 1, p. 91-98, 2008.

BARROS, F.; BORZONE, C. A.; ROSSO, S. Macroinfauna of six beaches near Guaratuba Bay, Southern Brazil. Braz. Arch. Biol. Tech., v. 44, n. 4, p. 351-364, 2001.

BLANKENSTEYN, A. O uso do caranguejo maria-farinha Ocypode quadrata (Fabricius) (Crustacea, Ocypodidae) como indicador de impactos antropogênicos em praias arenosas da Ilha de Santa Catarina, Santa Catarina, Brasil. Rev. Bras. Zool., v. 23, n 3, p. 870-876, 2006.

BORZONE, C. A.; SOUZA, J. R. B. Estrutura da macrofauna bentônica no supra, meso e infralitoral de uma praia arenosa do sul do Brasil. In: ABSALÃO, R.S.; ESTEVES, R.S. (Org.). Oecol. Brasiliensis. Rio de Janeiro, v. 3, p. 197-212, 1997.

BORZONE, C. A.; SOUZA, J. R. B.; SOARES, A. G. Morphodynamic influence on the structure of inter and subtidal macrofaunal communities of subtropical sandy beaches. Rev. Chil. Hist. Nat., v. 69, p. 565-577, 1996.

BROWN, A. C.; MCLACHLAN, A. Sandy shore ecosystems and the threats facing them: some predictions for the year 2025. Environ. Conserv., v. 29, n.1, p. 62-77, 2002.

CAETANO, C. H. S.; CARDOSO, R. S.; VELOSO, V. G.; SILVA, E. L. Population biology and secondary production of Excirolana braziliensis (Isopoda: Cirolanidae) in two sandy beaches of Southeastern Brazil. J. Coast. Res., v. 22, n. 4, p. 825-835, 2006.

CARDOSO, R. S.; VELOSO, V. G. Population biology and secondary production of the sandhopper Pseudorchestoidea brasiliensis (Amphipoda: Talitridae) in Prainha Beach, Brazil. Mar. Ecol. Prog. Ser., v. 142, p. 111-119, 1996.

CARDOSO, R. S.; VELOSO, V. G. Population dynamics and secondary production of the wedge clam Donax hanleyanus (Bivalvia: Donacidae) on a high-energy, subtropical beach of Brazil. Mar. Biol., v. 142, p. 153162, 2003. 
CLARKE, K. R.; WARWICK, R. M. Change in marine communities: an approach to statistical analysis and interpretation. Plymouth: Natural Environment Research Council, 1994. 144 p.

DE RUYCK, A. M. C.; SOARES, A. G.; MCLACHLAN, A. Human recreational patterns on beaches with different levels of development. T. Roy. Soc. S. Africa, v. 52, n. 2, p. 257-276, 1997.

DEAN, R. G. Heuristic models of sand transport in the surf zone. CONFERENCES ON ENGINEERING DYNAMICS IN THE SURF ZONE, Sydney, NSW, 1973. Proceedings ... p. 208-214, 1973.

DEFEO, O.; ALAVA, A. Effects of human activities on longterm trends in sandy beach populations: the wedge clam Donax hanleyanus in Uruguay. Mar. Ecol. Prog. Ser., v. 123, p. 73-82, 1995

DEFEO, O. E.; MCLACHLAN, A. Patterns, process and regulatory mechanisms in sandy beach macrofauna: a multi-scale analysis. Mar. Ecol. Prog. Ser., v. 295, p. 1$20,2005$.

DEFEO, O.; MCLACHLAN, A.; SHOEMAN, D. S.; SCHLACHER, A.; DUGAN, J.; JONES, A.; LASTRA, M.; SCAPINI, F. Threats to sandy beach ecosystems: A review. Estuar. Coast. Shelf Sci., v. 81, p. 112,2009 .

DUGAN, J. E; HUBBARD, D. M.; MCCRARY, M. D.; PIERSON, M. O. The response of macrofauna communities and shorebirds to macrophyte wrack subsidies on exposed sandy beaches of southern California. Estuar. Coast. Shelf Sci., v. 58 S, p. 25-40, 2003.

FANINI, L.; CANTARINO, C. M.; SCAPINI, F. Relationships between the dynamics of two Talitrus saltator populations and the impacts of activities linked to tourism. Oceanologia, v. 47, n. 1, p. 93-112, 2005.

FOLK, R. L.; WARD, W. C. Brazos River bar, a study in significance of grain size parameters. J. Sed. Petrol., v. 27, p. 3-26, 1957.

GHESKIERE, T.; VINCX, M.; WESLAWSKI, J. M.; SCAPINI, F.; DEGRAER, S. Meiofauna as descriptor of tourism-induced changes at sandy beaches. Mar. Environ. Res., v. 60, p. 245-265, 2005.

JARAMILLO, E.; CONTRERAS, H.; QUIJO`N, P. Macroinfauna and human disturbance on a sandy beach of South-Central Chile. Rev. Chil. Hist. Nat., v. 69, p. 655-663, 1996.

KNOX, G. A. The Ecology of Sea Shores. New York: CRC Press, 2000. $555 \mathrm{p}$

LERCARI, D.; DEFEO, O. Variation of a sandy beach macrobenthic community along a human-induced environmental gradient. Estuar. Coast. Shelf Sci., v. 58S, p. 17-24, 2003.

LLEWELLYN, P. J.; SHACKLEY, S. E. The effects of mechanical beach-cleaning on invertebrate populations. Br. Wildl., v. 7, p. 147-155, 1996.

LOZOYA, J. P.; DEFEO, O. Effects of a freshwater canal discharge on an ovoviviparous isopod inhabiting an exposed sandy beach. Mar. Freshwater Res. v. 57, p. 421-428, 2006.

MACCORD, F. S.; AMARAL, A. C. Z. The reproductive cycle of Scolelepis goodbodyi (Polychaeta, Spionidae). Mar. Biol.,v. 151, p. 1009-1020, 2007.

MAGALHÃES, W. F; LIMA, J. B.; BARROS, F.; DOMINGUEZ, J. M. L. Is Ocypode quadrata (Fabricius,
1787) a useful tool for exposed sandy beaches management in Bahia state (Northeast Brazil)? Braz. J. Oceanogr., v. 57, n. 2, p. 149-152, 2009.

MClACHLAN, A.; BROWN, A. The Ecology of Sandy Shores. New York: Academic Press, 2006. 373 p.

MCLACHLAN, A.; DORVLO, A. Global patterns in sandy beach macrobenthic communities. J. Coast. Res., v. 21, n. 4, p. 674-687, 2005.

MOFFETT, M. D.; MCLACHLAN, A.; WINTER, P. E. D.; DE RUYCK, A. M. C. Impact of trampling on sandy beach macrofauna. J. Coast. Conserv., v. 4, p. 87-90, 1998.

NARDI, M.; MORGAN, E.; SCAPINI, F. Seasonal variation in the free-running period in two Talitrus saltator populations from Italian beaches differing in morphodynamics and human disturbance. Estuar. Coast. Shelf Sci., v. 58S, p. 199-206, 2003.

NEVES, F. M.; BEMVENUTI, C. E. The ghost crab Ocypode quadrata (Fabricius, 1787) as a potential indicator of anthropic impact along the Rio Grande do Sul coast, Brazil. Biol. Conserv., v. 133, p. 43-435, 2006

NOY-MEIR, I. Structure and function of desert ecosystems. Israel J. Botany, v. 28, p. 1-19, 1979.

SCHREINER, R.; OZORIO, C.P. Dinâmica da fauna de insetos do supralitoral numa praia do Atlântico Sul: Estudo de curta duração. Biociências, v. 11, n. 2, p. 123$131,2003$.

SHORT, A. D. The role of wave height, period, slope, tide range and embaymentisation in beach classifications: a review. Revta Chil. Hist. Nat., v. 69, p. 589-604, 1996.

SHORT, A. D. Handbook of beach and shoreface morphodynamics. London: John Wiley, 1999. 379 p.

SOUZA, J. R. B. Produção secundária da macrofauna bentônica da Praia de Atami, Paraná, Brasil. Tese (Doutorado). Programa de Pós-Graduação em Ciências Biológicas-Zoologia/UFPR, 1998.129 p.

SOUZA, J. R. B.; BORZONE, C. A. Population dynamics and secondary production of Scolelepis squamata (Polychaeta: Spionidae) in an exposed sandy beach of southern Brazil. Bull. Mar. Sci., v. 67, n. 1, p. 221-233, 2000.

SOUZA, J. R. B.; BORZONE, C. A. Population dynamics and secondary production of Euzonus furciferus Ehiers (Polychaeta, Opheliidae) in an exposed sandy beach of Southern Brazil. Rev. Bras. Zool., v. 24, n. 4, p. 1139$1144,2007$.

SOUZA, J. R. B.; GIANUCA, N. M. Zonation ans seasonal variation of the intertidal macrofauna on a sandy beach of Paraná state, Brazil.Sci. Mar., v. 59, n.2, p. 103-111, 1995

SOUZA, J. R. B.; LAVOIE, N.; BONIFÁCIO, P. H.; ROCHA, C.M.C. Distribution of Ocypode quadrata (Fabricius, 1787) on sandy beaches of northeastern Brazil. Atlântica, v. 30, n. 2, p. 139-145, 2008.

SUGUIO, K. Introdução à sedimentologia. São Paulo: EDUSP,1973. 317 p.

UGOLINI, A.; UNGHERESE, G.; SOMIGLI, S.; GALANTI, G.; BARONI, D.; BORGHINI, F.; CIPRIANI, N.; NEBBIAI, M.; PASSAPONTI, M.; FOCARDI, S. The amphipod Talitrus saltator as a bioindicator of human trampling on sandy beaches. Environ Mar. Res., v. 65, p. $349-357,2008$ 
UNDERWOOD, A. J. Experiments in Ecology: Their logical design and interpretation using analysis of variance. Cambridge: Cambridge University Press, 1997. $504 \mathrm{p}$

VELOSO, V. G.; CARDOSO, R. S.; FONSECA, D. B. Spatio-temporal characterization of intertidal macrofauna at Prainha Beach (Rio de Janeiro state). In: ABSALÃO, R.S.; ESTEVES, R.S. (Org.). Oecol. Brasiliensis, Rio de Janeiro, v. 3, p. 213-225, 1997.

VELOSO, V. G.; SILVA, E. S.; CAETANO, C. H. S.; CARDOSO, R. S. Comparison between the macroinfauna of urbanized and protected beaches in Rio de Janeiro state, Brazil. Biol. Conserv., v. 127, p. 510 $515,2006$.

VELOSO, V. G.; NEVES, G.; LOZANO, M.; PEREZHURTADO, A.; GAGO, C. G.; HORTAS, F.; GARCIA, F. Responses of talitrid amphipods to a gradient of recreational pressure caused by beach urbanization. Mar. Ecol., v. 29, n. 1, p. 126-133, 2008.
VELOSO, V. G; SALLORENZO, I. A; FERREIRA, B. C. A.; SOUZA, G. N. Atlantorchestoidea brasiliensis (Crustacea: Amphipoda) as an indicator of disturbance caused by urbanization of a beach ecosystem. Braz. J. Oceanogr., v. 58, n. 1, p. 13-21,2009

VELOSO, V. G.; NEVES, G.; CAPPER, L. A. Sensitivity of a cirolanid isopod to human pressure. Ecol. Indicators, v.11, p. 782-788, 2011.

WESLAWSKI, J. M.; MALINGA, B. U.; KOTWICKI, L.; OPALINSKI, K.; SZYMELFENIG, M.; DUTKOWSKIB, M. Sandy coastlines. Are there conflicts between recreation and natural values? Oceanol. Stud., v. 29, n. 2, p. 5-18, 2000.

(Manuscript received 24 February 2011; revised 20 October 2011; accepted 20 March 2012) 